\title{
СОЦИАЛЬНОЕ УЧАСТИЕ СТУДЕНТОВ РОССИИ И АРМЕНИИ: ИНСТИТУЦИАЛЬНЫЙ КОНТЕКСТ И НЕРЕАЛИЗОВАННЫЙ ПОТЕНЦИАЛ НЕКОММЕРЧЕСКОГО СЕКТОРА В СОЦИОКУЛЬТУРНОМ РАЗВИТИИ РЕГИОНАЛЬНЫХ ГОРОДОВ
}

\begin{abstract}
В статье анализируется участие студентов России и Армении в социокультурном развитии городов, через локальные проекты некоммерческого сектора. Сравнивается институциальный контекст молодежного участия в этих странах. Проведен опрос студентов в городах Свердловской области (Российская Федерация) и населенных пунктах Ширакской области (Армения). Соотношение подвыборок соответствует распределению численности населения в сравниваемых регионах и отражает распределение молодежи по типам населенных пунктов в них. Исследование показало, что готовность студентов Армении к участию в проектах по развитию городов существенно выше, чем у российских студентов. Это свидетельствует о социальной активности армянского студенчества, сформированной определенной институциальной средой. При этом практики участия армянской и российской молодежи в культурном развитии городов не отличаются, уровень участия в обеих странах в целом невысок. Межстрановые различия определились тремя группами факторов. Во-первых, это уровень развития демократических гражданских инсти-
\end{abstract}

Мария Владимировна Певная - д.с.н., доцент, заведующая кафедрой социологии и технологий государственного и муниципального управления, Уральский федеральный университет, Екатеринбург. Россия. Электронная почта: m.v.pevnaya@urfu.ru

Елена Анатольевна Шуклина- д.с.н., профессор, кафедра социологии и технологий государственного и муниципального управления, Уральский федеральный университет, Екатеринбург. Россия. Электронная почта: e.a.shuklina@urfu.ru

Лилит Антоновна Асоян-к.ист.н., доцент, кафедра истории и философии, Ширакский государственный университет; преподаватель, кафедра экономики и управления, Международный научно-образовательный центр НАН Республики Армения, Ереван. Армения. Электронная почта: lilitasoyan@rambler.ru 
тутов и содержание государственной молодежной политики. В России централизованная государственная поддержка социальной активности студенчества не обеспечивает ожидаемого эффекта и не оказывает существенного влияния на культуру молодежного участия. В Армении национальная стратегия поддержки социального участия молодежи отсутствует и не способствует его реализации. Во-вторых, муниципалитеты взаимодействуют с локальными НКО, и это работает как институт гражданского общества, что обеспечивает условия для развития молодежного активизма. Но в России взаимодействие затруднено излишней бюрократизацией и профессионализацией НКО, их финансовой зависимостью от государства, в Армении - диаспоральные организации и международные фонды, активно финансирующие третий сектор, не вызывают доверия у молодежи. В-третьих, различия обусловлены уровнем культуры и практик социального участия студентов, мотивации и знаний, самоидентификацией с городом. При ряде схожих моментов у российских студентов культура патернализма в области социальной ответственности за состояние городов оказалась более выраженной.

Ключевые слова: социальное участие, молодежное волонтерство, развитие городов

DOI: $10.17323 / 727-0634-2020-18-3-445-460$

Активное привлечение молодежи к решению общественных и городских проблем - крайне актуальный вопрос современного управления. В стратегии молодежной политики ЕС до 2027 г. зафиксировано, что правительства стран союза должны активно сотрудничать с молодежью, способствуя ее участию в демократической жизни, поддерживать социальную и гражданскую активность, стремиться обеспечить молодым людям необходимые для этого ресурсы (European Union 2019). В европейских странах молодежь вовлекается в решение социальных проблем с помощью участия в проектах некоммерческих организаций, в инициативах сообществ и в социальных движениях (Paolini et al. 2018: 89). Во многих странах фиксируется рост молодежного волонтерства (European Youth 2018). Европейская молодежь отдает предпочтение локальным проектам, направленным на решение конкретных проблем своих сообществ, а глобальные программы менее популярны.

С помощью национального проекта «Образование» к 2024 г. планируется вовлечь в деятельность российских общественных объединений на базе образовательных организаций 8,8 млн молодых людей. Для этого в регионах создается система социальной поддержки граждан, систематически участвующих в добровольческих проектах. Приращение количественных показателей вовлечения молодежи в различные виды общественной активности - ключевая задача документа. Однако всегда ли количественные показатели социального участия связаны с его качеством? 
Насколько массовая вовлеченность молодых людей способна влиять на качество жизни городских сообществ, намерения горожан делать чтолибо для других жителей и города, в котором они живут?

По данным Фонда «Общественное мнение», в России за год с 7 до 14\% выросло число тех, кто называет себя добровольцем (Агентство стратегических инициатив 2019). В 2018 г. 11409 тыс. россиян было вовлечено в волонтерство, в том числе 5362 тыс. человек в возрасте от 18 до 30 лет и 4449 тыс. добровольцев-школьников (от 7 до 17 лет). В 2018 г. средняя численность добровольцев социально ориентированных некоммерческих организаций (СО НКО) составила 2937 тыс. человек (Министерство... 2019: 2). За 2019 г. на создание условий для социального участия только в Федеральном проекте «Социальная активность» потрачено 3 363,3 млн рублей. Однако выявлено, что в стране увеличивается разрыв между устойчивыми СО НКО и новыми инициативами и командами, усиливается конкуренция за дефицитные ресурсы (ЦИРКОН 2020). Закрепляется дистанция между классическими НКО и теми, кто развивает свои программы, ориентируясь на приоритеты, нормы и идеологию общественной деятельности, задаваемые государством.

В 2018 г. даже в Москве при высоком уровне декларируемой информированности граждан о деятельности НКО (63\%) из тех респондентов, кто заявил, что помогал незнакомым людям в последние два-три года, только 9\% сказали, что делали это в рамках мероприятий местных НКО, 23 \% из этой группы- респонденты в возрасте от 18 до 24 лет (ЦИРКОН 2018). Динамика развития культуры благотворительности в связке с развитием третьего сектора в России незначительна, как и в большинстве постсоветских стран. Если помогающее поведение и практики денежных пожертвований становятся более распространенными, то показатели участия в деятельности НКО меняются несущественно. Мировой рейтинг благотворительности $(W G I)$ показывает, что в таких странах, как Армения, Грузия, Латвия, Россия число людей, работающих волонтерами в НКО, практически не меняется на протяжении последних 5 лет. По данным 2019 г., из 143 стран Армения при расчете $W G I$ занимает 114 место, Россия- 117 (КАФ 2019:25). Россия смогла продвинуться в этом рейтинге за последние пять лет на 12 пунктов, Армения - на 24 пункта. При этом работали волонтерами в НКО в 2015 г. 16\% россиян (74 место), в 2019 г.- 19\% (75 место).

Нарастают противоречия глобальных тенденций и локальных процессов, сопряженных с социальной политикой (Ярская-Смирнова, Романов 2005: 498). При этом локализация молодежной активности в городских пространствах с конца XX в. становится не только предметом исследований, но и успешным объектом управленческого проектирования, подчёркивающего универсальную применимость и ценность участия молодежи в развитии местных сообществ (Driskell 2002). В статье дается оценка институциальных условий формирования социокультурного поля моло- 
дежного участия в двух бывших советских странах и определяется потенциал социального участия студенчества в некоммерческом секторе для социокультурного развития городов.

\section{Концептуализация социального участия молодежи в развитии городов и некоммерческого сектора}

Обозначим понятийную рамку исследуемой проблемы. Общественное участие рассматривается как процесс вовлечения и поддержания взаимодействия субъектов общественных отношений, осуществления целенаправленных или реактивных действий по совместному достижению значимого результата, включающий в себя взаимозависимые социальное (в пространстве повседневности), гражданское и политическое участие. При такой интерпретации за гражданским участием закрепляется вертикальное участие, связанное с процессами со-управления и принятия решений. Социальное участие локализуется на горизонтальном уровне и трактуется как коллективная деятельность, осуществляемая в рамках повседневной жизни и направленная на удовлетворение общественного интереса (Никовская, Скалабан 2017).

В структуре участия выделяются два взаимосвязанных компонента: институциальные возможности для реализации активной гражданской позиции и реальные практики действующих людей, основанные на их ценностях, взаимном доверии, солидарности (Савельев 2013). Эффективность реализации социального участия обусловлена не только пространством (местом жительства, работы, отдыха) и возникающими в его границах социальными отношениями, но и индивидуальными жизненными траекториями, включенностью в контекст деятельности некоммерческого сектора (Cahill, Dadvand 2018).

Существуют следующие виды социального участия горожан: помогающее поведение или волонтерство, благотворительность, предоставление информации и различных услуг; решение городских проблем, повышение качества жизни или активность сообществ по социальной проблематике; культурная, спортивная и досуговая активность горожан; творческие и профессиональные объединения; защита интересов отдельных социальных групп, имеющих потребность в учете своих специфических потребностей. В качестве наиболее типичных и распространенных форм активности, как правило, рассматривается помогающее поведение, а также общественно-полезная деятельность в рамках городских пространств (ЦИРКОН 2018: 5).

Социальное участие молодежи- значимый фактор развития территорий и территориальных сообществ с одной стороны, условие формирования чувства общности, связи с конкретным городом и городским сообществом, готовности быть активными, ответственными в реализации 
конкретных практик и инициатив в своем городе-с другой (Michels 2012). Разграничиваются четыре формы молодежного участия: гражданское участие, участие в межгрупповом диалоге, социально-политическом развитии и деятельности местных НКО (Checkoway, Aldana 2013). Если первые три формы связаны с политической активностью, взаимодействием молодежных организаций с чиновниками, то последняя сопряжена с повседневной жизнедеятельностью.

В управлении участием молодежи в России приоритет отдается организации общественно-политической активности. В последние годы фиксируется противоречивый характер политических настроений при низкой политической активности молодого поколения (Руденкин 2019) и поляризация установок молодежи в отношении волонтерства (Кисиленко 2018). При этом ценности гражданской ответственности, альтруизма и готовности к заботе об окружающих разделяет молодежь всех российских городов вне зависимости от групповых идентичностей и культурных предпочтений (Омельченко 2019), она не устраняется от политики, но создает новые формы участия, проявляя слабый интерес к политическим организациям.

\section{Характеристика исследования}

Исследование является частью масштабного авторского проекта изучения социального участия студенческой молодежи постсоциалистических стран. Сравнение России и Армении обусловлено, с одной стороны, сходным культурно-историческим опытом этих стран, с другой-существенными различиями институциальных условий для реализации социальной активности молодежи. Изучается студенчество российских городов в границах Свердловской области и армянских городов Ширакской области. Опрос проведен с применением онлайн-анкетирования. Ссылка на анкету инициативно размещалась в молодежных тематических группах в социальных сетях, непосредственно объединяющих студентов из разных городов и вузов. Целевая выборка включает 715 респондентов из 37 уральских городов и 20 населенных пунктов Армении (64\% женщин и $36 \%$ мужчин). В Свердловской области опрошено 465 студентов, в том числе $15 \%$ из Екатеринбурга, $30 \%$ респондентов из больших и средних городов области, $55 \%$ студентов из малых городов. В Ширакской области Армении опрошено 250 человек, в том числе $49 \%$ из регионального центра, Гюмри, $17 \%$ респондентов из больших и средних городов, из малых населенных пунктов$34 \%$. Соотношение подвыборок соответствует распределению численности населения в сравниваемых регионах и отражает распределение молодежи по типам населенных пунктов.

Выбор регионов для опроса объясняется тем, что вузы в этих регионах выступают центрами притяжения молодежи не только крупных, но и малых и средних городов. В исследовании оценивался опыт участия молодежи 
в социокультурном развитии городов и готовность к действиям, соучастию и включению в различные практики в оффлайн и онлайн форматах.

Для определения готовности студентов к разным видам участия в развитии городов в анкете сформулированы три вопроса: «Готовы ли присоединиться к горожанам, которые участвуют в субботниках, проводят городские праздники и социальные мероприятия?», «Готовы ли вы помогать в организации выставок, ярмарок, публичных мероприятий, где горожане и гости города смогут с пользой проводить свое время?», «Готовы ли вы участвовать в социальных проектах по городской тематике, например, рассказывать детям и подросткам о культуре, истории и архитектуре вашего города?». По этим трем показателям определялся сводный индекс готовности к социальному участию в социокультурном развитии города (в пределах долей единицы). Опыт волонтерства замерялся по ответам на вопрос: «Есть ли у вас опыт волонтерства?». Для оценки потенциала социальной активности молодежи применена четырехвекторная модель (Кисиленко 2018: 64).

\section{Институциальные условия социального участия молодежи России и Армении}

В России с 2005 г. началось активное формирование организационной инфраструктуры для социального участия, централизовано стали создаваться институты общественного контроля, которые должны обеспечивать связь государства и гражданского общества, правительство стало более активно и целенаправленно финансировать НКО и развивать всероссийские сетевые общественные движения. В РФ зарегистрировано 218 тыс. НКО (в 2016-223 тыс.), но активных около 15-20\% (Общественная палата РФ 2019: 66). Слабой стороной российских НКО является их финансово-экономическая зависимость от государства (Мерсиянова, Беневоленский 2017), нежелание людей участвовать в институциально закрепленных структурах гражданского общества (Evans at al. 2016:305), ограниченное влияние государства на стимулирование проектной и инновационной культуры в деятельности НКО (Смирнов 2016). В последнее время все более выраженными становятся субъектность и политизированность горожан, готовность принимать активное участие в судьбе своих городов. При парадоксальном развитии неформальной гражданской активности, формальная инфраструктура не предоставляет гражданам адекватных возможностей для такого участия (Желнина, Тыканова 2019). Получает дальнейшее развитие модель, оставшаяся в наследство от советского периода, массовых членских молодежных организаций. Практически исключены из ареала государственного содействия неправительственные организации, кроме малого числа прогосударственных структур, которым доверяются задачи воспитания молодежи (Silvan 2019). Под эгидой Ассоциации волонтерских 
центров (2020) запускаются региональные ресурсные центры- организации, выполняющие полный комплекс услуг по развитию волонтерства в 72 субъектах РФ.

Институты гражданского общества в Армении отличаются разнообразием и идеологическим плюрализмом, но не отражают в полной мере реальных запросов общества, не обеспечивают преодоления проблем и внутренних конфликтов. В 2018 г. в Армении зарегистрированы 4222 неправительственные организации, 1120 фондов и 244 ассоциации. Только 15-20\% из зарегистрированных организаций осуществляют активную деятельность (USAID 2019). Их финансирование, как правило, напрямую связано с общественными организациями армянских диаспор и международными фондами. Уровень доверия к НКО в обществе низкий: рассматриваются как «пожиратели грантов», чья деятельность не имеет реальной связи с проблемами общества. Некоторый позитивный сдвиг общественного мнения наметился в 2018 г. Опрос Международного республиканского института показал увеличение доли респондентов, положительно относящихся к НКО (IRI 2018). Существуют проблемы общественного контроля и государственного надзора за НКО, особенно на региональном уровне, когда власти могут не знать о деятельности НКО и не учитывать ее при разработке программ развития.

Формальные механизмы, с помощью которых можно развивать сотрудничество органов власти с НКО, остаются слабыми или отсутствуют вовсе, а способность власти реагировать на общественные нужды и потребности через НКО в стране ограничена. В противовес деятельности НКО в городах Армении наметился поворот к неформальной гражданской активности. Эта активность нового типа, которая сфокусирована на конкретных событиях, в значительной степени спонтанна, в основном движима молодежью и поддерживается социальными сетями (Freedom House 2018). НКО не поддерживают эти формы активности, но их члены как частные лица активно участвуют в гражданских инициативах (Paturyan 2015).

В России концептуальные основы молодежной политики прописаны на национальном уровне в нормативно-правовом поле до 2025 г. (Распоряжение... 2014). Финансирование молодежной политики, молодежных организаций и инициатив осуществляется централизовано по трем направлениям: информирование молодежи о возможности дальнейшего саморазвития, научной, творческой, социально-политической активности; поддержка талантливой и инициативной молодежи; гражданское образование и патриотическое воспитание. Такой централизованный подход не позволяет включать в поле молодежной политики всю вариативность молодежных групп и сообществ, фиксировать сигналы региональных и локальных молодежных проблем, идущие от самой молодежи. Работа с молодежью преимущественно вписана в национальный проект «Образование». Ставка сделана на вовлечение молодежи в деятельность объ- 
единений на базе школ, ссузов и вузов, на массовой работе, всероссийских и окружных проектах.

В Армении разработана национальная стратегия по расширению молодежного участия в политической жизни и гражданских инициативах. Среди целей новой правительственной программы (2019)- повышение социальной, политической, гражданской активности молодежи. Правительственная программа не устанавливает сроков и показателей для измерения того, как эта цель будет достигнута. Участие молодежи в общественно-политической, социально-экономической и культурной жизни- один из основных принципов концепции государственной молодежной политики (Правительство Республики... 2014). Участие определяется как прямое и косвенное вовлечение молодежи, активных молодежных групп, а также молодежных НКО в принятие решений во всех сферах общественной жизни. В документе фиксируются уровни участия: осведомленность, участие в общественных консультациях, в принятии решений, инициирование и мониторинг социальных программ бенефициарами. Правительство разрабатывает механизмы партнерства молодежи, государственной финансовой поддержки молодежных НКО в рамках молодежной политики. При этом 31,3\% молодежи считает, что правительство в реализации политики не принимает во внимание проблемы молодежи, а 25,8 \% полагает то же об органах местного самоуправления (Independence Generation 2016).

\section{Типология социального участия студенчества в социокультурном развитии городов}

Оценка потенциала социального участия студентов осуществлялась через сопоставление показателей наличия опыта и готовности к волонтерской деятельности. Уровень готовности как среднее значение сводного индекса для России - 0,46, для Армении - 0,72. Доля студентов готовых к социальному участию (ГСУ $>0,5)$ в России $42 \%$, в Армении $-81 \%$. У российских студентов уровень готовности к участию в социокультурном развитии города статистически значимо ниже, чем у студентов в Армении $(\mathrm{U}$ Манна-Уитни $=27521,5 ; \mathrm{W}$ Вилкоксона $=135866,5 ; \mathrm{Z}=11,012$; асимпт. знач. $(2$-стор.) $=0,000,<0,01)$. Реальная вовлеченность студенчества в волонтерскую деятельность практически не имеет различий по странам. И в России, и в Армении по 46\% студентов имеют волонтерский опыт. Оказывается сходной и структура вовлеченности: среди имеющих опыт участия $28 \%$ студентов из России и $30 \%$ из Армении получили его в вузе, инициировавшем волонтерские проекты. Участвовали в различных акциях за пределами вуза, в том числе в локальных НКО $18 \%$ российских и $16 \%$ армянских студентов.

Результаты исследования, представленные в разрезе векторов готовности/неготовности к социальному участию и наличию/отсутствию опыта 
волонтерской деятельности, позволили построить матрицу типов социального участия студентов вузов в социокультурном развитии города (рис.1). Схема показывает, что в рассматриваемых странах ситуация принципиально различна. В России потенциал социального участия невысок, молодежь не стремиться проявлять гражданскую активность: нет ни опыта (53\%), ни желания участвовать в городских проектах (58\%). Для большинства молодых россиян это вынужденная вовлеченность, формальное участие с доминирующей мотивацией «все равно от меня ничего не зависит».
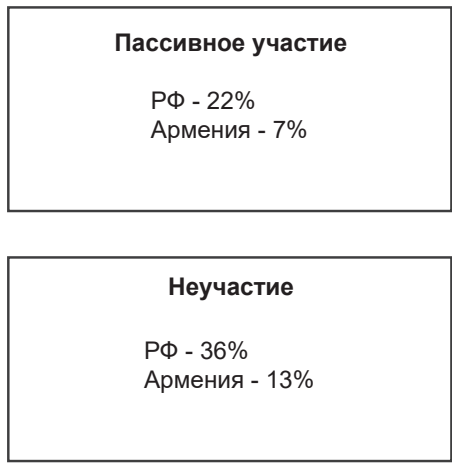
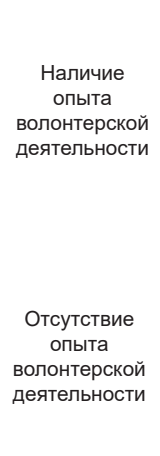

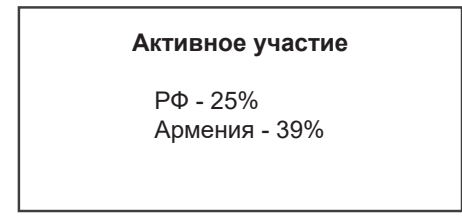

Потенциальное участие

РФ - $17 \%$

Армения - $41 \%$

Рисунок 1 . Типы участия студентов вузов в социокультурном развитии города (в \% от опрошенных по странам)

Ситуация в Армении существенно отличается. Для студенческой молодежи характерен высокий уровень готовности к социальному участию, которая, однако, оказывается нереализованной на уровне конкретных практик. Имеющийся потенциал социального участия студенчества оказывается незадействованным. Соответственно, в Армении стоит принципиально иная, нежели в России, задача, которая заключается в создании условий для активного включения молодежи в различные формы участия, инициирование социальных проектов как в онлайн, так и офлайн форматах, отвечающих их потребностям и интересам.

Особенности культуры участия студенческого сообщества связаны с уровнем идентификации молодых людей с городом. Так, 30,2\% российских и 55,6\% армянских студентов отмечают, что знают историю своего города; 79,4\% молодых россиян и 95,4\% армян уверены, что состояние культурно-исторических мест и достопримечательностей проблемно и требует активного вмешательства. При этом характер участия студенчества связан с выбором основных акторов, призванных влиять на улучшение состояния культурно-исторических мест города (респонденты отвечали на вопрос: «Как вы думаете, кто прежде всего должен вносить 
свою лепту в улучшение состояния объектов вашего города?»). Если россияне, базируясь на патерналистских представлениях о социальной ответственности за состояние своих городов, считают основной группой влияния городских чиновников (61,1\%), а потом уже и всех горожан $(44,5 \%)$, то армянские студенты уверены в обратном. Для них ключевое влияние на улучшение состояния объектов культурно-исторического наследия и культурно-исторических мест города должны оказывать прежде всего сами горожане (70,0\%), а затем уже и администрация города $(40,9 \%)$.

Готовность студентов к развитию городской среды связана с субъективной оценкой ее культурной значимости. Так, по мнению $35,4 \%$ российских и 56,1\% армянских студентов, культурно-исторические объекты города представляют ценность для всех горожан; 25,3\% россиян и 48,5\% армян считают, что они интересны для туристов, поскольку рассказывают об истории города. Социокультурный контекст формирования различия в мотивации во многом определяют региональные особенности. В Армении- многовековое развитие культуры городов в Ширакской области, возникших в V в. до н.э. В уральском регионе активный процесс осмысления ценности индустриального наследия, сформированного в XVIII-XX вв., начался лишь в последние десятилетия. Культурную значимость для города объектов именно этих исторических периодов отмечают армянские и российские студенты в своих ответах. С готовностью студентов к развитию городской среды также коррелирует длительность проживания студента и его семьи: $79,6 \%$ россиян и $88,6 \%$ армян живут в городах более 10 лет и планируют после окончания вуза там работать (43,4\% и 60,2\% соответственно).

\section{Заключение}

Вовлечение молодежи в социокультурное развитие городов- тенденция последнего десятилетия. По данным сравнительных исследований, студенчество- наиболее активная группа молодежи, с высокой мотивацией и опытом социального участия. Результаты нашего исследования показали, что гражданская позиция у армянских студентов существенно отличается от российской, потенциал социальной активности высок, и институциальная среда оказывает непосредственное влияние на формирование этого потенциала. Однако реальные практики участия молодежи в России и Армении существенно не отличаются. В целом для них характерен невысокий уровень социального участия.

Потенциал социального участия армянской молодежи проявляется в выраженном противоречии между: (1) высоким уровнем ее потребности и готовности к участию в развитии городской среды, сформированным благодаря интересу к историческому прошлому и культуре города, с одной стороны, и отсутствием востребованных молодежью организационных условий для его реализации, с другой; (2) активным финансированием 
третьего сектора диаспоральными организациями и международными фондами и низким уровнем доверия к ним со стороны студенческой молодежи, негативно влияющим на активность, массовость, инициативность молодежного участия в их деятельности; (3) складывающимися в стране институциальными условиями для открытого взаимодействия демократических институтов гражданского общества с государственными структурами, с одной стороны, и отсутствием желания студенческой молодежи работать на развитие города в формальных организациях и проектах, инициированных муниципалитетами, с другой.

Потенциал социального участия российской молодежи проявляется в противоречиях между: (1) наличием нормативных условий для реализации различных видов волонтерской деятельности и сформированной у студентов культурой патернализма; (2) организационными усилиями вузов по вовлечению молодежи в деятельность волонтерских объединений и снижением мотивации в ситуации вынужденной вовлеченности; (3) интересом студенческой молодежи к городской проблематике и низким потенциалом инициатив некоммерческих организаций и муниципалитетов по привлечению молодежных сообществ к развитию городской среды.

В целом, институциальные условия социального участия студенческой молодежи на макроуровне определяются развитием институтов гражданского общества и ориентацией государственной молодежной политики на развитие социального участия, на микро уровне- степенью сформированности культуры и практик социального участия молодежи, их мотивацией, идентификацией с городом, траекторией территориального транзита во время учебы и трудоустройства. А в контексте повседневности мотивация студентов к развитию городской среды коррелирует с представлениями о значимости культурно-исторических объектов.

\section{Выражение признательности}

Исследование выполнено при финансовой поддержке РФФИ в рамках научного проекта № 20-011-00471. Работа выполнена при поддержке Правительства РФ (№ 02.А03.21.0006).

\section{Список источников}

Агентство стратегических инициатив (2019) Итоги Года добровольца в России. Доступно по ссылке: https://asi.ru/news/101750/ (дата обращения: 20 января 2020).

Ассоциация волонтерских центров (2020) О программе «Ресурсные центры». Доступно по ссылке: https://xn-80ae4d.xn-plai/regional (дата обращения: 20 января 2020).

Желнина А.А., Тыканова Е.В. (2019) Формальные и неформальные гражданские инфраструктуры: современные исследования городского локального активизма в России. Журнал социологии и сочиальной антропологии, 22 (1): 162-192. 
КАФ (2019) Мировой рейтинг благотворительности. Доступно по ссылке: https:/ clck.ru/PkrJu (дата обращения: 15 февраля 2020).

Кисиленко А. В. (2018) Волонтерство: потенциал самоорганизации российской молодежи. Научный результат. Социология и управление, 4 (1): 63-71.

Мерсиянова И.В., Беневоленский В.Б. (2017) НКО как поставщики социальных услуг: верификация слабых сторон. Вопросы государственного и муниципального управления, (2): 83-104.

Министерство экономического развития РФ (2019) Доклад о развитии добровольчества в РФ в 2018 году. Доступно по ссылке: https://clck.ru/PkrL9 (дата обращения: 20 февраля 2020).

Никовская Л.И., Скалабан И.А. (2017) Гражданское участие: особенности дискурса и тенденции реального развития. Полис. Политические исследования, (6): 43-60.

Омельченко Е.Л. (2019) Уникален ли российский случай трансформации молодежных культурных практик? Мониторинг общественного мнения: экономические и социальные перемены, (1): 3-27.

Общественная палата РФ (2019) Доклад о состоянии гражданского общества в Российской Федерации за 2019 год. Доступно по ссылке: https:/clck.ru/MaYKq (дата обращения: 25 февраля 2020).

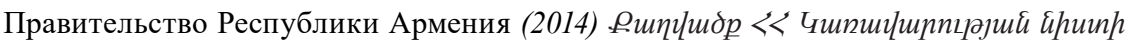

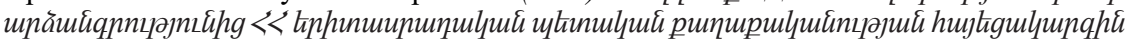

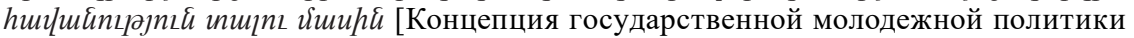
в Республике Армения] № 54 от 25.12.2014. Доступно по ссылке: https:/clck.ru/PkrVe (дата обращения: 10 марта 2020).

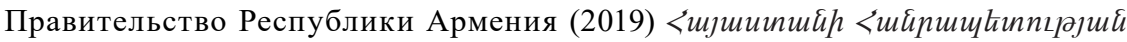

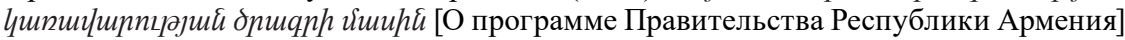
№ 65 от 08.02.2019. Доступно по ссылке: https://clck.ru/PkrXS (дата обращения: 10 марта 2020).

Распоряжение Правительства РФ (2014) Основы государственной молодежной политики РФ на период до 2025 года № 2403-р от 29.11.2014.

Руденкин Д.В. (2019) Протестные настроения российской молодежи через год после митингов 2017 г. Социодинамика, (2): 23-33.

Савельев Ю.Б. (2013) Основные типы участия в общественной жизни европейских стран. Сочиологические исследования, (12): 64-71.

Смирнов В.А. (2016) Проектная деятельность российских некоммерческих организаций: ключевые проблемы и противоречия. Сочиологические исследования, (2): $62-69$.

ЦИРКОН (2018) Неинституичональная социальная активность граждан. Доступно по ссылке: https://clck.ru/PkrPg (дата обращения: 25 февраля 2020).

ЦИРКОН (2020) Инфраструктура российского благотворительного сектора. Доступно по ссылке: https://clck.ru/PkrQb (дата обращения: 20 февраля 2020).

Ярская-Смирнова Е.Р., Романов П.В. (2005) Новая идеология и практика социальных услуг: оценка эффективности в контексте либерализации социальной политики. Журнал исследований социальной политики, 3 (4): 497-522. 
Bartels K.P.R., Cozzi G., Mantovan N. (2013) The Big Society, Public Expenditure and Volunteering. Public Administration Review, 3 (2): 340-351.

Cahill H., Dadvand B. (2018) Re-conceptualising Youth Participation: A Framework to Inform Action. Children and Youth Services Review, (95): 243-253.

Checkoway B., Aldana A. (2013) Four Forms of Youth Civic Engagement for Diverse Democracy. Children and Youth Services Review, (35): 1894-1899.

Driskell D. (2002) Creating Better Cities with Children and Youth. A Manual for Participation. London: Earthscan.

Evans A. B., Henry L.A., Sundstrom L. (2016) Russian Civil Society: A Critical Assessment. London: Routledge.

European Union (2019) The EU Youth Strategy for 2019-2027. Доступно по ссылке: https:// clck.ru/PkrZc (дата обращения: 12 января 2020).

European Youth (2018). European Union: EC. Доступно по ссылке: https://clck.ru/PkrZz (дата обращения: 11 января 2020).

Freedom House (2018) Nations in Transit: Armenia Country Profile. Доступно по ссылке: https://clck.ru/Pkrcf (дата обращения: 28 февраля 2020).

Independence Generation (2016) Youth Study 2016-Armenia. Yerevan: Friedrich-EbertStiftung.

IRI (2018) Public Opinion Survey: Residents of Armenia. Доступно по ссылке: https:// clck.ru/PkreR (дата обращения: 28 февраля 2020).

Michels A. (2012) Citizen Participation in Local Policy Making: Design and Democracy. International Journal of Public Administration, 35 (4):285-292.

Nalecz S., Les E., Pielinski B. (2015) Poland: A New Model of Government-Nonprofit Relations for the East? Voluntas: International Journal of Voluntary and Nonprofit Organizations, (26): 2351-2378.

Paolini G., Horváth A., Motiejūnaitè A. (2018) Situation of Young People in the European Union Commission. Brussels: EC.

Paturyan Y.J. (2015) Armenian Civil Society: It is Not All About NGOs. Caucasus Analytical Digest, (73): 2-5.

Silvan K. (2019) Youth Policy Practice in Post-Soviet Russia and Belarus: Past and Present. Universe of Russia, 28 (1): 161-171.

Smith D. H., Stebbins R. A., Grotz J. (2016) The Palgrave Hand-book of Volunteering, Civic Participation, and Nonprofit Associations. Houndmills: Palgrave Macmillan.

USAID (2019) Civil Society and Media in Armenia. Доступно по ссылке: https://clck. $\mathrm{ru} / \mathrm{PkrgB}$ (дата обращения: 28 февраля 2020). 
Maria Pevnaya, Elena Shuklina, Lilit Asoyan

\title{
SOCIAL PARTICIPATION OF RUSSIAN AND ARMENIAN STUDENTS: THE INSTITUTIONAL CONTEXT AND UNREALISED POTENTIAL OF THE THIRD SECTOR IN THE SOCIO-CULTURAL DEVELOPMENT OF REGIONAL CITIES
}

\begin{abstract}
The article examines the potential of student participation in the socio-cultural development of cities. We consider the possible impact of youth social participation through volunteerism on the development of cities in which they live through local projects in the non-profit sector in Russia and Armenia. The article assesses the implementation of youth policy as an institutional context for youth participation. A survey was conducted among thirty-seven cities of the Sverdlovsk region in Russia and twenty settlements of the Shirak region in Armenia (target sample, $\mathrm{N}=715$ ). The study showed that the readiness of Armenian students to participate in the socio-cultural development of cities is significantly higher in comparison with the assessments of Russian students. The students of Russia and Armenia are characterized by a low level of social participation in the cultural development of cities. Cross-country differences were determined by three main factors. Firstly, the level of development of civil institutions does not have a straightforward relationship with state policy encouraging youth participation. In Russia, centralized state support for the social activity of students does not provide the expected significant impact on the youth participation. In Armenia, the lack of a national strategy to support the youth participation does not allow state support to be fully realized. Secondly, the degree to which municipalities interact with local NGOs supports the development of civil society, something that helps provide conditions for constructive youth participation. In Russia, these interactions are limited due to the excessive bureaucratization of NGOs and their financial dependence on the state. In Armenia, interactions are encouraged with the active financing of diaspora's organizations and international foundations. These well-funded organisations, however, do not inspire confidence or trust among the youth of Armenia. Thirdly, differences between Russia and Armenia can be explained by the level to which a culture of student participation exists.
\end{abstract}

Keywords: social participation, youth volunteering, urban development

DOI: $10.17323 / 727-0634-2020-18-3-445-460$

\footnotetext{
Maria Pevnaya- Dr. Sci. (Soc.), chair of sociology and public administration technologies, Ural Federal University named after the first President of Russia B. N. Yeltsin, Ekaterinburg, Russian Federation. Email: m.v.pevnaya@urfu.ru

Elena Shuklina-Dr. Sci. (Soc.), professor of sociology and public administration technologies, Ural Federal University named after the first President of Russia B. N. Yeltsin, Ekaterinburg, Russian Federation. Email: e.a.shuklina@urfu.ru

Lilit Asoyan - PhD (History), associate professor of history and philosophy, Shirak State University; associate professor of economy and management of The National Academy of Sciences of Armenia, Yerevan, Republic of Armenia. Email: lilitasoyan@rambler.ru
} 


\section{References}

Agency of Strategic Initiatives (2019) Itogi Goda dobrovol'ca v Rossii [Results of the Year of Volunteers in Russia]. Available at: https://asi.ru/news/101750/ (accessed 20 January 2020).

Association of Volunteer Centers in RF (2020) O programme Resursnye centry [Resource Centers Program]. Available at: https://xn-80ae4d.xn-plai/regional (accessed 20 January 2020).

Bartels K.P.R., Cozzi G., Mantovan N. (2013) The Big Society, Public Expenditure and Volunteering. Public Administration Review, 3 (2):340-351.

CAF (2019) World Giving Index. Available at: https://clck.ru/PkrJu (accessed 15 February 2020).

Cahill H., Dadvand B. (2018) Re-conceptualising Youth Participation: A Framework to Inform Action. Children and Youth Services Review, (95):243-253.

Checkoway B., Aldana A. (2013) Four Forms of Youth Civic Engagement for Diverse Democracy. Children and Youth Services Review, (35): 1894-1899.

CIRKON (2018) Neinstitutsional'naya sotsial'naya aktivnost' grazhdan [Noninstitutional Social Activity of Citizens]. Available at: https://clck.ru/PkrPg (accessed 25 February 2020).

CIRKON (2020) Infrastruktura rossiiskogo blagotvoritel'nogo sektora [Infrastructure of the Russian Charity Sector]. Available at: https://clck.ru/PkrQb (accessed 20 February 2020).

Driskell D. (2002) Creating Better Cities with Children and Youth. A Manual for Participation. London: Earthscan.

Evans A. B., Henry L.A., Sundstrom L. (2016) Russian Civil Society: A Critical Assessment. London: Routledge.

European Union (2019) The EU Youth Strategy for 2019-2027. Available at: https://clck.ru/PkrZc (accessed 12 January 2020).

European Youth (2018) European Union: EC. Available at: https://clck.ru/PkrZz (accessed 11 January 2020).

Freedom House (2018) Nations in Transit: Armenia Country Profile. Available at: https://clck. ru/Pkrcf (accessed 28 February 2020).

Government of the Republic of Armenia (2014) K'ag vaçk'HH Karavarowtyan nisti arjangrowtyownic' HH eritasradakan petakan k'agak'akanowtyan hayec'akargin havanowtyown talow masin [The Concept of State Youth Policy in the Republic of Armenia] N 54 from 25.12.2014. Available at: https://clck.ru/PkrVe (accessed 10 March 2020).

Government of the Republic of Armenia (2019) Hayastani Hanrapetowtyan karavarowtyan çragri masin [On the Program of the Government of the Republic of Armenia] N 65 from 08.02.2019. Available at: https://clck.ru/PkrXS (accessed 10 March 2020).

Independence Generation (2016) Youth Study 2016-Armenia. Yerevan: Friedrich-Ebert-Stiftung. IRI (2018) Public Opinion Survey: Residents of Armenia. Available at: https://clck.ru/PkreR (accessed 28 February 2020).

Kisilenko A. V. (2018) Volonterstvo: potentsial samoorganizatsii rossiyskoy molodezhi [Volunteering: Potential for Self-organization of Russian Youth]. Nauchnyy rezul'tat. Sotsiologiya i upravlenie [Scientific Result. Sociology and Management], 4 (1): 63-71.

Mersiyanova I. V., Benevolenskij V.B. (2017) NKO kak postavshchiki social'nyh uslug: verifikaciya slabyh storon. [NPOs as Social Services Providers: Organizational Weaknesses Verifying]. Voprosy gosudarstvennogo i municipal'nogo upravleniya [Public Administration Issues], (2): 83-104.

Michels A. (2012) Citizen Participation in Local Policy Making: Design and Democracy. International Journal of Public Administration, 35 (4): 285-292.

Ministry of Development of the Russian Federation (2019) Doklad o razvitii dobrovol'chestva $v R F v 2018$ godu [Report on the Development of Volunteerism in Russia in 2018]. Available at: https://clck.ru/PkrL9 (accessed 20 February 2020). 
Nalecz S., Les E., Pielinski B. (2015) Poland: A New Model of Government-Nonprofit Relations for the East? Voluntas: International Journal of Voluntary and Nonprofit Organizations, (26): 2351-2378.

Nikovskaya L.I., Skalaban I. A. (2017) Grazhdanskoe uchastie: osobennosti diskursa i tendentsii real'nogo razvitiya. [Civil Participation: Features of Discourse and Trends of Real Development]. Polis. Politicheskie issledovaniya [Polis. Political Research], (6): 43-60.

Omelchenko E. L. (2019) Unikalen li rossiyskiy sluchay transformatsii molodezhnykh kul'turnykh praktik? [Is the Russian Case of Transformation of Youth Cultural Practices Unique?]. Monitoring obshchestvennogo mneniya: Ekonomicheskie i sotsial'nye peremeny [Monitoring Public Opinion: Economic and Social Changes], (1):3-27.

Paolini G., Horváth A., Motiejūnaitė A. (2018) Situation of Young People in the European Union Commission. Brussels: EC.

Paturyan Y.J. (2015) Armenian Civil Society: It is Not All About NGOs. Caucasus Analytical Digest, (73): 2-5.

Public Chamber of the Russian Federation (2019) Doklad o sostojanii grazhdanskogo obshhestva $v$ Rossijskoj Federacii za 2019 god [Report on Civil Society in the Russian Federation in 2019]. Available at: https://clck.ru/MaYKq (accessed 20 February 2020).

Order of the Government of the Russian Federation (2014) Osnovy gosudarstvennoy molodezhnoy politiki RF na period do 2025 goda [Fundamentals of the State Youth Policy of the Russian Federation for the Period Up to 2025] N 2403-r from 29.11.2014. Available at: http://static.government.ru/media/files/ceFXleNUqOU. (accessed 28 February 2020).

Rudenkin D. V. (2019) Protestnye nastroeniya rossiyskoy molodezhi cherez god posle mitingov 2017 g. [Protest Moods of Russian Youth a Year after the 2017]. Sotsiodinamika [Sociodynamics], (2):23-33.

Savelev Y.B. (2013) Osnovnye tipy uchastiya v obshchestvennoy zhizni evropeyskikh stran. [Main Types of Participation in the Public Life of European Countries]. Sotsiologicheskie issledovaniya [Sociological Research], (12): 64-71.

Smirnov V.A. (2016) Proektnaya deyatel 'nost' rossijskix nekommercheskix organizacij: klyuchevy'e problemy` i protivorechiya. [Project Activity of Russian Non-profit Organizations: Key Problems and Contradictions]. Sociologicheskie issledovaniya [Sociological Research], (2): 62-69.

Silvan K. (2019) Youth Policy Practice in Post-Soviet Russia and Belarus: Past and Present. The Universe of Russia, 28 (1): 161-171.

Smith D.H., Stebbins R. A., Grotz J. (2016) The Palgrave Hand-book of Volunteering, Civic Participation, and Nonprofit Associations. Houndmills: Palgrave Macmillan.

USAID (2019) Civil Society and Media in Armenia. Available at: https://clck.ru/PkrgB (accessed 20 February 2020).

Yarskaya-Smirnova E.R., Romanov P. V. (2005) Novaya ideologiya i praktika sotsial'nykh uslug: otsenka effektivnosti v kontekste liberalizatsii sotsial'noy politiki [New Ideology and Practice of Social Services: Efficiency Assessment in the Context of Social Policy Liberalization]. Zhurnal Issledovanii Sotsial'noi Politiki [The Journal of Social Policy Studies], 3 (4):497-522.

Zhelnina A., Tykanova E. (2019) Formal'nyye i neformal'nyye grazhdanskiye infrastruktury: sovremennyye issledovaniya gorodskogo lokal'nogo aktivizma v Rossii [Formal and Informal Civic Infrastructure: Contemporary Studies of Urban Local Activism in Russia]. Zhurnal sotsiologii i sotsialnoy antropologii [The Journal of Sociology and Social Anthropology], 22 (1): 162-192. 